\title{
Investors Behavior, Governance and Earnings Management: Under and over Reaction to Information
}

\author{
Afraa Khzouri ${ }^{\mathrm{a}}$, Amira Neffati ${ }^{\mathrm{b}}$ \\ ${ }^{a}$ ESC Tunis, Campus Universitaire, La Manouba 2010, Tunisia \\ ${ }^{b}$ ISG Tunis, 41, Rue de la Liberté, Le Bardo 2000, Tunisia
}

\begin{abstract}
The aim of this paper is to study the relationship between earnings management, governance and investors behavior, since this latter can inform about the nature of earnings management and can be considered as a governance mechanism to reduce accounts manipulations. On the basis of a sample of 700 American firms for the period of 1996-2006, our empirical results show that investors who take short positions, are able to interpret the information detected from the earnings management. The activity of these investors may be considered as an indicator of the quality of the governance structure and the presence and nature of earnings management. The under-reaction of investors to information leads to short-term sale of the shares of poorly governed firms and characterized by an opportunistic earnings management and to invest in firms well-governed and characterized by an informational earnings management therefore an abnormal profit can be realized.
\end{abstract}

Key Words: Earnings management, Governance, investor's behavior.

JEL code: G12; G15

\section{(C) 2014 Published by SSBFNET}

\section{Introduction}

Based on these assumptions of the strong efficiency of financial markets, investors can rationally anticipate events that may influence stock prices of firms. So markets are information based efficient.

However, for over thirty years, the results of a number of researches provide a crack in this building. Various anomalies remain unexplained including the inappropriate response to information, particularly earnings management, which is a consequence of asymmetric information.

Indeed, the results of several studies on U.S. over-reaction [De Bondt and Thaler (1985)] and under-reaction [Bernard and Thomas (1989), Jegadeesh and Titman (1993)] suggest that investors do not react properly to the information they receive. They commit cognitive errors that can be profitably exploited by others. These findings call into question the theory thus efficiency of financial markets in semi-strong sense.

A variety of hypotheses and explanations have been proposed and given to the phenomena of under and over-reaction on the international stock markets and emerging whose errors of measurement, the effect January [Chopra et al. (1992)], size, ratio of book-to-market [Fama and Eng (1992, 1993, 1996)] and behavioral explanations [De Bondt and

\footnotetext{
${ }^{a}$ Corresponding author. Afraâ khzouri.
} 
Thaler (1985), Jegadeesh and Titman (1993) and Chan et al. (1996)]. The development of the behavioral approach in economics and finance attempts to explain these phenomena by the behavior patterns of investors. Behavioral models lately tries to reconcile the phenomena of over-reaction and under-react with earnings managing.

The assumptions of investor behavior and / or heterogeneity of investors predicts a sub-reaction to public information and recent over-reaction to the historical information. On the one hand, we see a difficulty in reconciling the results of empirical studies and theoretical models of behavior, and secondly, the absence of explanatory factors of the phenomena of under-reaction and overreaction (Fama, 1998).

We propose in this paper to explain the under-reaction and overreaction of investors to information through the earnings management and governance. Indeed, if investors under-react to information in the short term, earnings management is partially integrated in the course of action. Thus, they sell the shares of poorly governed firms and characterized by an opportunistic earnings management, following the incorporation of information from accounting manipulations and taking into account the process of reversal to the mean of discretionary accruals, the prices of securities will be lower.

\section{Literature Review}

\subsection{Stock performance and earnings management: the phenomena of under and over-reaction to information}

Behavioral finance has two opposite phenomena related to investor behavior. The overreaction of investors to information is the first phenomenon [De Bondt and Thaler $(1985,1987)]$. This phenomenon means that all information is included in the course of the long term.

While the under-reaction, which is the second phenomenon, means that stock prices do not reflect the totality of the information in the short term. Bernard and Thomas (1989) showed that good or bad information is not immediately incorporated into stock prices in the short term. This information is measured by the degree of surprise in the most recent announcements of results compared with analysts' expectations, the price does not reflect the short term but it fits the long-term information.

The phenomenon of under-reaction is closely related to the effect momentum or momentum implies that the securities, whose returns were good during the previous year, will continue their momentum on the following exercises while securities, including performance was poor, their situation will not improve next year.

In financial markets, one of the most important indicators of performance is shareholder value. The importance of this indicator is more relevant than this value is related to income. However, the market value is related to stock prices that do not reflect the totality of information due to information asymmetry and market inefficiency. That is why studies on the phenomena of under and over-reaction is increased. Studies on these phenomena have been motivated by the existence of winning strategies. Indeed, these strategies were the basis for the detection of these phenomena.

Bernard and Thomas (1989) formed two portfolios of firms. They are based on the announcement of good news or bad news as a criterion for selection of firms in each portfolio. It follows that the first portfolio consists of companies that recently announced good news while the second portfolio is composed of the companies bearing bad news.

Within six months following the formation of two portfolios, the two researchers found that the initial portfolio companies have achieved a return of $6 \%$ higher than that achieved by the firms of the second portfolio.

Based on our results of Bernard and Thomas (1989), we can say that investors revise their forecasts upward after the announcement of good news and it is the logic underlying the two phenomena of the sub and over-reaction.

The succession of good news leads investors to continually revise their forecasts upwards until they end up believing in the good condition of the company (Dinh, 2005).

May (1992) studied the phenomenon of over-reaction to information on the U.S. stock market. He showed that in the long term the logic of this phenomenon involves a reversal of stock returns following the announcement of important information about the company such as the results.

The ways in which investors react to information studied in several researches are varied (Fama and French, 1992, 1993, 1995, 2000; Black, 2001 and Knez and Ready, 1997). Despite the variety of these results, the success of winning strategies could not be explained so far neither the thesis of the couple return-risk (Fama and French, 1992, 1993, 1995, 2000) nor by criticism addressed methods of data mining (Black, 2001 and Knez and Ready, 1997). 
Indeed, Fama and French have said their three-factor model is not able to explain all the anomalies in the stock market, a factor not taken into account the results management and its effect on stock price .

According to behavioral finance theorists, changes in stock prices can be explained by psychological reasons. Kahneman and Tversky (1974) were based on the concept of bounded rationality in investor psychological biases. Indeed, under the assumptions of behavioral finance often checked, everyone is guilty of systematic errors in perceiving and processing information.

For proponents of the behavioral approach, the study of stock market requires the use of factors other than financial, such as those studied in the social sciences (psychology and sociology).

Several behavioral models have been developed. Each model fits the positive serial correlation in the short term and negative long-term course assuming different assumptions about the nature of behavioral biases and / or heterogeneity of investors.

Several studies in social psychology have been interested in human judgments. They interpret the process by which individuals form and change its belief about its environment. The rationality of an individual does not always predictable human judgments. Instead the powers of life and the predictions are subject to bias and systematic errors. These biases are designated by the cognitive biases in the psychological literature.

Senkowski et al. (1995) and Dinh (2005) have found that cognitive biases are due to the limited capacity of individuals to obtain and process all the information potentially available. This limitation in turn implies systematic errors so that judgments deviate from accepted norms and standards.

As for Kahneman and Tversky (1974), they tried to explain the overreaction of stock prices to new judgments by representativeness heuristics. The representativeness heuristic is considered a preconceived idea that would guide the naive judgments. Then they explained the sub-reaction of stock prices in recent news by advancing the idea that investors do not revise their beliefs enough by the anchoring mechanism. This mechanism is manifested in the numerical estimates when a person has made an estimate and cannot adjust to new data (Kahneman and Tversky, 1974). Hence, this mechanism can lead to over-estimate the likelihood of disjoint events and an under-estimation of the joint probability of occurrence of events.

\subsection{The under and over-reaction to information and earnings management:}

Financial markets include two groups of investors: informed investors called sophisticated investors and uninformed investors called noise traders. The first group of investors has an influence on the determination of securities prices, these informed investors may destabilize stock returns because they are able to anticipate the behavior of uninformed investors (Atron, 2002, Lee and Swaminathan 2000 and Jegadeesh and Titman, 2001).

Uninformed investors choose their portfolios based on incorrect beliefs. They under-react to information in the short term. Atron (2002), Lee and Swaminathan (2000) and Jegadeesh and Titman (2001) showed that these uninformed investors prefer to sell the securities of poorly governed firms anticipating the presence of an opportunistic earnings management and they behave followers by purchasing securities firms with good governance practices.

To conclude, we will try to study the impact of investor activity on earnings management in function of governance structure. This allows us to formulate the following hypothesis:

\section{H: taking a short position by selling the shares of poorly governed firms and characterized by an opportunistic earnings management has a positive effect on abnormal return}

\section{Research Methodology}

In this section, we begin by describing the sample. Then we will present the models used and the empirical results.

\subsection{The sample}

Our analysis is based on a sample of 700 U.S. firms. We divided the sample into two portfolios. The first portfolio consists of firms with good governance practices and characterized by an informational earnings management and the second portfolio consists of poorly governed firms and characterized by an opportunistic earnings management. 
Financial data were collected manually annual reports, balance sheets and income statements.

\subsection{The model and results}

Our empirical approach has two basic steps.

3.2.1 Step 1: the relationship between earnings management, governance and the abnormal return:

In a first step, we will try to determine for each group the relationship between earnings management, the abnormal return and the variables of ownership structure. To test this relationship, we will build on the model of Beneish and Vargus (2002) as follows:

Abnormal return $=\beta_{0}+\beta_{1}$ discretionary Accruals $+\beta_{2}$ CEO ownership $+\beta_{3}$ managerial ownership $+\beta_{4}$ ownership of institutional investors $+\beta_{5}$ ownership of majority investors $+\varepsilon$

The variables used are as follows:

Abnormal return: the excess return of a portfolio $\left(R_{p, t}-R_{f, t}\right)$ will be measured by the performance of the strategy buy and hold

Discretionary accruals: measurement of earnings management

CEO (chief executive officer) ownership: Shares owned by CEO

Managerial ownership: Shares owned by internals

Ownership of institutional investors: Shares owned by institutional investors

Ownership of majority investors: Shares owned by majority investors

The results of the regression model described above by the method of ordinary least squares for the firms of the first portfolio are presented in Table 1 next:

Table 1: Relationship between Earnings Management, the Abnormal Return and the Variables of Ownership Structure for Firms in the First Portfolio

Dependent Variable: Abnormal Return

\begin{tabular}{|c|c|c|c|c|}
\hline Variable & Coefficient & Std. Error & t-Statistic & Prob. \\
\hline Discretionary accruals & 2.106358 & 0.667705 & 3.154621 & 0.0000 \\
\hline CEO ownership & 1.132100 & 0.531802 & 2.128796 & 0.0000 \\
\hline Managerial ownership & 3.001254 & 0.964200 & 3.112687 & $\begin{array}{l}0.0000 \\
0.0000\end{array}$ \\
\hline Ownership of institutional investors & 2.125461 & 0.687824 & 3.090120 & $\begin{array}{l}0.0000 \\
0.0000\end{array}$ \\
\hline Ownership of majority investors & 2.123659 & 0.786915 & 2.698714 & $\begin{array}{l}0.0000 \\
0.0000\end{array}$ \\
\hline$R$-squared & 0.86124 & \multicolumn{2}{|c|}{ Mean dependent var } & 120.2541 \\
\hline Adjusted $R$-squared & 0.802131 & \multicolumn{2}{|c|}{ S.D. dependent var } & 169.4521 \\
\hline S.E. of regression & 85.62541 & \multirow{2}{*}{\multicolumn{2}{|c|}{$\begin{array}{l}\text { Sum squared resid } \\
\text { Durbin-Watson stat }\end{array}$}} & 11054290 \\
\hline F-statistic & 92.42134 & & & 1.94123 \\
\hline $\operatorname{Prob}(F$-statistic) & 0.00000 & & & \\
\hline
\end{tabular}

In light of the findings and presented in Table 1, we can say that the explanatory power of the model is important because the $\mathrm{R}_{2}$ is $86.12 \%$ and the Fisher $\mathrm{F}$ is very high (92.42) 
The results allow us to assert that the coefficient of discretionary accruals is positive and significant, those of the majority ownership, institutional investors, the CEO and the managerial ownership are also positive and significant.

Based on our results found, we can say that investors sophisticated of the first portfolio, recognizing the good governance of their companies have no incentive to sell the shares of these firms. Being the most informed, they convey the right information about their companies to other investors, less informed, through an informational earnings management encouraging them not to sell the securities of these firms. Given the transparency of these enterprises, information is immediately available to all investors who can make accurate predictions.

Our results are consistent with previous studies. Indeed, Gugler (2001), and Oyvind Odegaard (2003) argued that the abnormal returns realized on the sale of shares of firms with good governance practices is low. Bhagat and Black (2002) have also shown that the market value increases with the degree of transparency of companies with good governance practices.

The results of the regression model described above by the method of ordinary least squares for the firms of the second portfolio are presented in Table 2 next:

Table 2: Relationship between Earnings Management, the Abnormal Return and the Variables of Ownership Structure for Firms in the Second Portfolio:

Dependent Variable: Abnormal Return

\begin{tabular}{|c|c|c|c|c|}
\hline Variable & Coefficient & Std. Error & t-Statistic & Prob. \\
\hline Discretionary accruals & 1.524136 & 0.762899 & 1.997819 & 0.0000 \\
\hline CEO ownership & 2.005468 & 0.848343 & 2.363981 & 0.0000 \\
\hline Managerial ownership & 3.009874 & 0.912615 & 3.298073 & $\begin{array}{l}0.0000 \\
0.0000\end{array}$ \\
\hline Ownership of institutional investors & -3.110125 & 0.721508 & -4.310587 & $\begin{array}{l}0.0000 \\
0.0000\end{array}$ \\
\hline Ownership of majority investors & -1.723614 & 0.700999 & -2.458796 & $\begin{array}{l}0.0000 \\
0.0000\end{array}$ \\
\hline$R$-squared & 0.850023 & \multicolumn{2}{|c|}{ Mean dependent var } & 120.10065 \\
\hline Adjusted R-squared & 0.803254 & \multicolumn{2}{|c|}{ S.D. dependent var } & 171.12587 \\
\hline S.E. of regression & 82.564110 & \multirow{2}{*}{\multicolumn{2}{|c|}{$\begin{array}{l}\text { Sum squared resid } \\
\text { Durbin-Watson stat }\end{array}$}} & 10612034 \\
\hline F-statistic & 90.16 & & & 1.932101 \\
\hline $\operatorname{Prob}(F$-statistic) & 0.00000 & & & \\
\hline
\end{tabular}

In light of the findings and presented in Table 2, we can say that the model's explanatory power is high because the $\mathrm{R}_{2}$ is $85 \%$ and the Fisher $\mathrm{F}$ is high (90.16)

It is clear from reading the table 2 that the coefficient of discretionary accruals is high, positive and significant, those of the majority ownership, institutional investors are negative and significant and that of the CEO ownership and managerial ownership are positive and significant. The interpretation of these coefficients allows us to conclude that the more informed investors (the internal and the CEO) adopt an opportunistic behavior by expropriating the wealth of 
the less informed investors. These carry an abnormal yield significant short term through the sale of shares of poorly governed firms and characterized by an opportunistic earnings management.

And Oyvind Odegaard (2003) argued that the abnormal return is higher when companies are making bad governance practices. In addition, Bhagat and Black (2002) showed that the abnormal return is an increasing function of the opportunistic earnings management for a sample of poorly governed firms.

\subsubsection{Second Step: Investor Behavior and Earnings Management}

The results found in regressions of the first step for companies in both portfolios have enabled us to determine the relationship between the abnormal return, earnings management and ownership structure as an indicator of investor activity. Indeed, the less informed investors are able to detect the nature of earnings management in a future period based on the process of reversal to the mean followed by accruals and from the governance structures. Hence, they can make a significant abnormal profit.

To determine the impact of the activity and behavior of investors on the earnings management and the possibility of an abnormal profit, we relied on the model Yang Zhang (2002), however, some changes are made, such that the introduction of discretionary accruals variables and abnormal returns.

The specification of the model of Zhang (2002) is as follows:

$\%$ Of shares sold $=\beta_{0}+\beta_{1}$ Accrauls discretionary $+\beta_{2}$ Option Dummy $+\beta_{3}$ rate of dividend $+\beta_{4}$ abnormal return $+\beta_{5}$ $R M+\varepsilon$

The variables used are as follows:

Abnormal return: the excess return of a portfolio $\left(\mathrm{R}_{\mathrm{p}, \mathrm{t}}-\mathrm{R}_{\mathrm{f}, \mathrm{t}}\right)$ will be measured by the variable performance of the strategy buy and hold

Discretionary accruals: measurement of earnings management

RM: Market Performance

Option dummy: binary variable that takes the value 1 if the portfolio includes options 0 if not

The results of the regression model of Zhang (2002) by the method of ordinary least squares for the firms of the first portfolio are presented in Table 3 next: 
Table 3: Relationship between the investment behavior of the first portfolio earnings management and abnormal return:

Dependent variable: \% of shares sold

\begin{tabular}{|c|c|c|c|c|}
\hline Variable & Coefficient & Std. Error & t-Statistic & Prob. \\
\hline Discretionary accruals & -1.658412 & 0.527171 & -3.145871 & 0.0000 \\
\hline Option dummy & -2.987100 & 0.994842 & -3.002587 & 0.0000 \\
\hline Rate of dividend distribution & -2.031258 & 0.676795 & -3.001289 & $\begin{array}{l}0.0000 \\
0.0000\end{array}$ \\
\hline Abnormal return & 2.001254 & 0.477269 & 4.193154 & 0.0000 \\
\hline RM & 1.070815 & 0.50553 & 2.118170 & 0.0000 \\
\hline$R$-squared & 0.818310 & \multicolumn{2}{|c|}{ Mean dependent var } & 150.11006 \\
\hline Adjusted R-squared & 0.785214 & \multicolumn{2}{|c|}{ S.D. dependent var } & 157.23543 \\
\hline S.E. of regression & 89.239871 & \multirow{2}{*}{\multicolumn{2}{|c|}{ Sum squared resid }} & 10751654 \\
\hline F-statistic & 95.87 & & & 1.873456 \\
\hline $\operatorname{Prob}(F$-statistic) & 0.00000 & & & \\
\hline
\end{tabular}

Given the results of regression for the first portfolio, we can affirm the good quality of the model as the $R_{2}$ is 0.8183 and the $\mathrm{F}$ of Fisher is 95.87.

It is clear from reading the table 3 that the variable abnormal return is positively correlated to the sale of shares in well governed firms. While the variable rate of dividend distribution, earnings management and option dummy is negatively correlated to the indicator of the activity of investors who take short positions.

Indeed, the sale of shares of firms that are transparent, well governed and that distribute dividends is less common in the market. Several empirical studies have shown that the abnormal return is low by selling shares of well-governed companies (Black, 2001 and Black, Jang and Kim, 2002).

The results of the regression model of Zhang (2002) by the method of ordinary least squares for the firms of the second portfolio are presented in Table 4 next: 
Table 4: Relationship between the behavior of investors in the second portfolio earnings management and abnormal return:

Dependent variable: \% of shares sold

\begin{tabular}{|c|c|c|c|c|}
\hline Variable & Coefficient & Std. Error & t-Statistic & Prob. \\
\hline Discretionary accruals & 2.118547 & 0.701713 & 3.019106 & 0.0000 \\
\hline Option dummy & 1.001231 & 0.333715 & 3.000251 & 0.0000 \\
\hline Rate of dividend distribution & -0.989512 & 0.380828 & -2.598314 & $\begin{array}{l}0.0000 \\
0.0000\end{array}$ \\
\hline Abnormal return & 2.615384 & 0.734222 & 3.562138 & 0.0000 \\
\hline RM & -1.931258 & 0.644159 & -2.998103 & 0.0000 \\
\hline$R$-squared & 0.899781 & \multicolumn{2}{|c|}{ Mean dependent var } & 136.12684 \\
\hline Adjusted R-squared & 0.871250 & \multicolumn{2}{|c|}{ S.D. dependent var } & 153.16498 \\
\hline S.E. of regression & 84.236511 & \multirow{2}{*}{\multicolumn{2}{|c|}{$\begin{array}{l}\text { Sum squared resid } \\
\text { Durbin-Watson stat }\end{array}$}} & 11576103 \\
\hline$F$-statistic & 96.21 & & & 1.912223 \\
\hline Prob(F-statistic) & 0.00000 & & & \\
\hline
\end{tabular}

In light of the regression results for the second portfolio, we can say a good model's explanatory power since the $\mathrm{R}_{2}$ is 0.8997 and the $\mathrm{F}$ of Fisher is 96.21.

The coefficients of discretionary accruals, abnormal return and the variable option are positive and highly significant. These results allow us to assert that the shares of poorly governed firms with opportunistic earnings management are the most sold on the market and the sale of these shares allows informed investors to earn abnormal returns.

The rate coefficient of dividend is negative and significant. Indeed, investors prefer to sell shares of companies that generally do not distribute a lot of dividends.

Our results are consistent with those found by Black (2001) and Black, Jang and Kim (2002). These researchers showed that the abnormal return increases by selling the shares of poorly governed firms.

We can therefore conclude that investors, who take short positions, are able to interpret the information detected from the earnings management. The activity of these investors may be considered as an indicator of the quality of the governance structure and the presence and nature of earnings management as they invest in firms well-governed and characterized by an informational earnings management. The under-reaction of investors to information leads to shortterm sale of the shares of poorly governed firms and characterized by an opportunistic earnings management and transparent investment firms enabling them to make an abnormal profit.

Previous research has shown that investors, who take short positions, are able to identify overvalued securities (Figlewski, 1981; Dechow et al, 2001 and Desai et al., 2002). These investors have the ability and financial incentives 
encouraging them to be active in firms with high levels of discretionary accruals. They represent groups of sophisticated investors, a reference for others and a way to detect accounting manipulation practices.

However, the sale of securities of companies with high discretionary accruals generates a very high cost and the activity of taking a short position becomes more risky. Indeed, firms with high discretionary accruals tend to have a low ratio of book to market and many opportunities for growth.

The results of previous studies show that firms with high discretionary accruals are small businesses with low transaction volumes, many opportunities for growth, low book to market ratio and low dividend payout ratio ( Scott et al., 2003).

Scott et al. (2003) argued that investors who take short positions in the market are more active in the portfolios of firms with a high performance management, low market capitalization and the same conditions mentioned above.

\section{Conclusion}

In this article, following the division of the sample into two portfolios, the first consisting of firms with good governance practices and characterized by an informational earnings management and the second consisting of poorly governed firms and characterized by an opportunistic earnings management, we determined for each group the relationship between performance management, governance and investor behavior.

To verify the relationship cited above, we proceeded in two stages. In a first step, we tested the relationship between the abnormal return, earnings management and the variables of ownership structure. Primary outcomes were found allow us to assert that investors in the portfolio of firms with good governance practices and characterized by an informational earnings management are aware that they have no interest in selling the shares of these firms due to proper management of their managers as investors portfolio firms badly governed and characterized by an opportunistic earnings management can earn high abnormal profit by selling the very shares of these companies and buying securities of well-governed firms. The managers of these firms, with private information and adopting opportunistic behavior, are able to earn a higher return (Black, 2001; Black, Jang and Kim, 2002; Klapper and Love, 2002 and Durnev and Kim, 2003).

In a second step, we tested the impact of the activity and behavior of investors on the earnings management and the possibility of an abnormal profit.

The results show that investors of the first portfolio companies have no incentive to sell the shares of such companies that are transparent, well governed and distribute dividends. While the shares of poorly governed firms with opportunistic earnings management are the most sold on the market and the sale of these shares allows investors to earn abnormal return (Gugler, 2001, Bhagat and Black, 2002, and Oyvind Odegaard, 2003). The activity of these investors may be considered as an indicator of the presence and the nature of earnings management and the quality of governance structure. 
The results found allow us to say that investor activity may influence the degree of earnings management and the opportunity to earn an abnormal profit. Indeed, taking a short position by selling the securities of poorly governed firms can be explained by managerial opportunism (Brown, Lee, Taylor and Walter, 2004 and Venkatachalam et al., 2003). This position can therefore be considered as a control mechanism to reduce opportunistic accounting manipulations and an indicator of the presence and nature of these practices.

\section{References}

Beneish M. D. and Vargus M. E. (2002), Insider Trading, Earnings Quality and Accrual Mispricing, The Accounting Review, vol 30, p. 421-452.

Bernard Victor L. and Thomas Jacob K. (1989), Evidence that stock prices do not fully reflect the implications of current earnings for future earnings, Journal of Accounting Research, vol 49, p. 307-343.

Bernard Victor L. and Thomas Jacob K. (1989), Postearnings-announcement drift: Delayed price response or risk premium?, Journal of Accounting Research (Supplement), vol 27, p. 136.

Bhagat, Black \& Blair (2002), Relational investing and firm performance, Working Paper, www.ssrn.com.

Black B (2001), the legal and institutionnel preconditions for strong securities markets, ULCA Law Review, vol 48, p. 781-855.

Black, Jang \& Kim (2002), Does corporate governance matter? Evidence from Korean market, Asian Corporate Governance Conference in Seoul, Korea.

Chan, Louis K. C., Jegadeesh Narasimhan and Lakonishok Josef (1996), Momentum strategies, Journal of Finance, vol 51, p. 1681-1713.

Chopra N., Lakonishok J. \& Ritter Jay R. (1993), Measuring Abnormal Performance: Do the U.S. Improve a Firm's Information Environment et Increase Market Value? Journal of accounting research.

DeBondt Werner F. M. \& Thaler R. (1987), Further evidence of investor overreaction and stock market seasonality, Journal of Finance, vol 42, p. 557-581.

DeBondt Werner F. M. \& Thaler R. (1985), Does the stocks market overreact? , Journal of Finance, vol 40, p. 793808 .

Dechow; Hutton, Meublroek \& Sloan (2001), Short sellers fundatamental analysis and stock returns, working paper University of Michigan and Harvard business school Boston MA.

Desai, Ramensh, Thiagarajan \& Balachandrean (2002), Short Selling and Corporate Malfeasance, Working paper, www.ssrn.com.

Dinh Thanh Huong (2005), Performance boursière à court et à long terme suite à l'annonce des résultats annuels : une approche comportementale », working paper, www.ssrn.com.

Durnev, Artyom \& Kim E. Han (2003), To Steal or Not to Steal: Firm Attributes, Working Paper, www.ssrn.com.

Fama E.F. (1998), Market efficiency, longterm returns and behavorial finance, Journal of Financial Economics, vol 49, p. 283-306. 
Fama E. F. \& French K. (1993), Common risk factors in the returns on stocks and bonds, Journal of financial Economics, vol 33, p. 356.

Fama E.F. \& French K. (1992), The crosssection of expected stock returns, Journal of finance, vol 47, N², p. 427465.

Fama E. F. \& French K. (1996), Size and BooktoMarket factors in earnings and returns, Journal of Finance, vol 50, p. 131-155.

Fama Eugene F \& French Kenneth R. (2000), Disappearing dividends: changing firm characteristics or lower propensity to pay?, Working paper, www.ssrn.com.

Figlewski S (1981), The information journal effect of restrictions on short sales some empirical evidence, Journal of finance, p.427-465.

Jegadeesh N. \& Titman S. (1993), Returns to buying winners and selling losers: Implications for stock market efficiency, Journal of Finance, vol 48, p. 65-91.

Jegadeesh N. \& Titman S. (2001), Profitability of momentum strategies: An evaluation of alternative, Journal of Finance.

Klapper L \& Love I. (2003), corporate governance investor protection and performance in emerging markets, Journal of corporate finance forthcoming.

Knez P.J. \& Ready M.J. (1997), On The Robustness of Size and Book to Market in Cross Sectional Regressions, The Journal of Finance, vol LII, N4 - September 97.

Knez P.J. \& Ready M.J. (1997), On The Robustness of Size and Book to Market in Cross Sectional Regressions, The Journal of Finance, vol LII, Nº4 - September 97.

Knez P.J. \& Ready M.J. (1997), On The Robustness of Size and Book to Market in Cross Sectional Regressions, The Journal of Finance, vol LII, N4 - September 97.

La Porta Rafael, Lakonishok J., Shleifer A. \& Vishny R.W. (1997), Good news for value stocks: Further evidence on market efficiency, Journal of Finance, vol 52, p. 859-874.

Mai H. (1992), Stratégie de sur-réaction et corrélation des rentabilités sur le marché français des actions de 1977 à 1990, Cahier de recherche du CEREG, Université ParisDauphine.

Oyvind Bohren \& Odegaard Brent Arne (2003), Corporate governance and economic performance, working papers.

Scott Richardson, Tuna Irem \& Wu Min (2003), Capital Market Pressures and Earnings Management: The case of earnings restatements, working paper.

Senkowska E. \& Orsero H (1995), Irrationalités collectives, Edition Delachaux et Niestlé.

Zhang Huai, 2002, Detecting Earning Management-Evidence from Rounding-up in Reported EPS, working paper, WwW.ssrn.com.

Zhang Yan, 2002, Do short sellers detect earnings management?, working papers, www.ssrn.com 